\title{
Modelling the vertical distribution of bromoform in the upper water column of the tropical Atlantic Ocean
}

\author{
I. Hense ${ }^{1, *}$ and B. Quack ${ }^{2}$ \\ ${ }^{1}$ Leibniz Institute for Baltic Sea Research, Rostock, Germany \\ ${ }^{2}$ Leibniz Institute of Marine Sciences, IFM-GEOMAR, Kiel, Germany \\ *now at: University of Hamburg, KlimaCampus, IHF, Grosse Elbstr. 133, 22767 Hamburg, Germany
}

Received: 30 September 2008 - Published in Biogeosciences Discuss.: 16 December 2008

Revised: 26 March 2009 - Accepted: 26 March 2009 - Published: 7 April 2009

\begin{abstract}
The relative importance of potential source and sink terms for bromoform $\left(\mathrm{CHBr}_{3}\right)$ in the tropical Atlantic Ocean is investigated with a coupled physicalbiogeochemical water column model. Bromoform production is either assumed to be linked to primary production or to phytoplankton losses; bromoform decay is treated as light dependent (photolysis), and in addition either vertically uniform, proportional to remineralisation or to nitrification. All experiments lead to the observed subsurface maximum of bromoform, corresponding to the subsurface phytoplankton biomass maximum. In the surface mixed layer, the concentration is set by entrainment from below, photolysis in the upper few meters and the outgassing to the atmosphere. The assumed bromoform production mechanism has only minor effects on the solution, but the various loss terms lead to significantly different bromoform concentrations below $200 \mathrm{~m}$ depth. The best agreement with observations is obtained when the bromoform decay is coupled to nitrification (parameterised by an inverse proportionality to the light field). Our model results reveal a pronounced seasonal cycle of bromoform outgassing, with a minimum in summer and a maximum in early winter, when the deepening surface mixed layer reaches down into the bromoform production layer.
\end{abstract}

\section{Introduction}

A considerable part of the ozone destruction in the troposphere and stratosphere is attributed to bromine species gen-

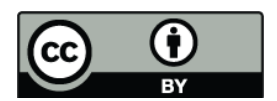

Correspondence to: I. Hense (inga.hense@uni-hamburg.de) erated by photolysis of bromoform $\left(\mathrm{CHBr}_{3}\right)$ of oceanic origin (see, e.g. Sturges et al., 2000). Hence, bromomform sources and sinks in the ocean are of interest for studying atmospheric trace gas cycles. Tropical oceans are particularly important, because high concentrations of inorganic bromine species and large air-sea fluxes of organic bromine species are found onshore and offshore (see Read et al., 2008; Quack et al., 2007a,b); tropical stratospheric upwelling might transport these trace gases from the boundary layer into the stratosphere.

Recent $\mathrm{CHBr}_{3}$ observations in the tropical eastern Atlantic Ocean (Quack et al., 2004, 2007b) have revealed a pronounced subsurface maximum at the depth of the subsurface chlorophyll maximum, suggesting a phytoplanktonic source of bromoform. This is consistent with laboratory experiments and field data that point to a coupling between bromoform production and phytoplankton growth for diatoms and cyanobacteria (Moore et al., 1996; Schall et al., 1996; Karlsson et al., 2008). Whether $\mathrm{CHBr}_{3}$ production serves a specific purpose (e.g., protection against grazing and cell poisoning by hydrogen peroxide - see e.g. Manley, 2002) or has to be regarded as the byproduct of another process is currently not known. It can also not be ruled out that bromoform is produced during the decay of organic matter, i.e. dead phytoplankton (Quack and Wallace, 2003) when the enzyme bromoperoxidase (necessary to catalyse the reaction with bromide ions) is set free. Whatever be the case, a relationship between $\mathrm{CHBr}_{3}$ production and growth/decay of phytoplankton seems highly plausible. Alternative ideas about open ocean bromoform sources (coastal production by macroalgae and/or advective transport, see e.g., Moore and Tokarczyk, 1993; Carpenter and Liss, 2000) are not considered for this region. 
Several processes have been found responsible for the reduction of $\mathrm{CHBr}_{3}$ concentrations in the ocean: Outgassing to the atmosphere may be the major factor in the surface mixed layer (see Quack et al., 2004). Other known decay processes include halide substitution of $\mathrm{CHBr}_{3}$ which leads to an estimated oceanic half life between 5 and 74 years (at $25^{\circ} \mathrm{C}$ and $2^{\circ} \mathrm{C}$, respectively) as well as hydrolysis working ten to hundred times slower (Geen, 1992; Vogel et al., 1987). In addition, it is assumed that photolysis plays an important role in the decay of $\mathrm{CHBr}_{3}$ in the surface ocean (Carpenter and Liss, 2000). Several biologically mediated processes accelerate bromoform degradation. Fetzner (1998) suggest a dehalogenation by bacteria during the decomposition of organic material. Recent observations indicate that two other processes are likely to be involved as well. The observed increase in the concentrations of dibromethane and decrease of bromoform point towards a reductive debromination (Quack et al., 2004). The underlying mechanisms are not understood, yet, but it seems that debromination is linked to heterotrophic activities (e.g. remineralization) (Quack et al., 2007b). The second process involves a cometabolism of bromoform during nitrification. The decay of bromoform has been shown to be more rapid in the presence of Nitrosomonas europaea which oxidizes ammonium to nitrite (Wahman et al., 2005). The pronounced nitrite maximum below the subsurface chlorophyll maximum layer in the oligotrophic open ocean (data from Meteor expedition M55, Wallace and Bange, 2004) might be an indication of not only nitrification, i.e. ammonium oxidation (Olson, 1981), but also enhanced bromoform decomposition. There is observational evidence of a decrease of $\mathrm{CHBr}_{3}$ in the nitracline, where nitrification is usually maximum (Quack, unpublished data from the Meteor cruise 60/5).

In summary, the magnitude of water column losses, their vertical distribution and their effect on surface mixed layer bromoform concentrations and the associated outgassing are only poorly understood (see e.g., Abrahamsson et al., 2004). In this study, we use numerical modelling to elucidate the role of different sources and sinks of open ocean $\mathrm{CHBr}_{3}$ in controlling the oceanic bromoform levels and the resulting air-sea flux.

\section{Model philosophy}

As pointed out above, little is known about the production and decay of bromoform within the water column. One might even argue that our understanding of water column sources and sinks of $\mathrm{CHBr}_{3}$ is inadequate to set up a model, given the existing uncertainties in the magnitude and relative role of various processes. On the other hand the research history has shown that modeling activities may foster future investigations in field and laboratory. From this point of view we find it the right time to address this important topic in the active field of organic halogen research. Our conceptual modelling study must be seen as a starting point, not the final word. Our current approach is based on the following arguments and assumptions:

First, we note that there seem to be fewer potential source than sink processes for $\mathrm{CHBr}_{3}$ in the ocean. The production is either assumed to be proportional to phytoplankton growth or phytoplankton death. In our study we investigate both cases separately; this specified source process forms the basis for numerical experiments. The degradation of bromoform is likely to depend on a number of processes, acting simultaneously but with varying strength in different parts of the water column. The strategy here is to include as many processes as necessary to obtain a realistic profile. Of course, our combinations may not be unique, but we can quantify the uncertainties.

The next step is to specify the functional dependence of the source and sink terms. Bromoform production is linearly coupled to primary production (or phytoplankton loss; see below). The decay processes are assumed to be either constant in time and space (attributed to hydrolysis, halide substitution for this particular region) or time- and depthdependent as a function of certain environmental factors (e.g. UV-irradiance) or biological processes (e.g. remineralization, nitrification).

Finally we need to specify the rates of these production and decay processes. The production rate is taken from laboratory studies on selected phytoplankton species (see below). The loss rates have been adjusted to obtain a high degree of similarity between the observed and simulated bromoform profiles (maximum, surface and deep ocean concentrations, vertical gradients).

\section{Model setup}

\subsection{Physical model setup}

The physical model is the one-dimensional water column model GOTM (General Ocean Turbulence Model, Umlauf et al., 2005, www.gotm.net). The model has been previously applied to several oceanic regimes, including the oligotrophic subtropical North Atlantic Ocean (BATS: Bermuda Atlantic Time-series Study, Weber et al., 2007) and the Baltic Sea (Burchard et al. 2006).

Here, GOTM is configured for the Cape Verde region in the eastern tropical North Atlantic Ocean. The model set-up is based on the BATS case, with only few modifications: a relatively high minimum value for turbulent kinetic energy (TKE) of $10^{-5} \mathrm{~m}^{2} \mathrm{~s}^{-2}$ is prescribed to parameterise the effects of double diffusion in this region (see e.g., MartínezMarrero et al., 2008). In addition, we have applied the bulk air-sea parameterisation for heat and freshwater fluxes of Fairall et al. (1996). The model covers the upper $700 \mathrm{~m}$ of the ocean; the lower boundary has been placed at this depth because it is close to the nutrient maximum where the diffusive 
fluxes vanish (see also Beckmann and Hense, 2007). The vertical resolution is $1 \mathrm{~m}$ and the time step $1 \mathrm{~h}$.

\subsection{Biogeochemical model setup}

Our ecosystem model is based on the relatively simple nitrogen-phytoplankton-zooplankton-detritus (NPZD) model of Schartau and Oschlies (2003). In its optimized configuration the model has also been applied basinwide (coupled to an ocean circulation model) for the equatorial (the focus of our study) and North Atlantic Ocean without changes in parameters (Oschlies and Schartau, 2005). Weber et al. (2007) have coupled the biogeochemical model to GOTM for their study of the oligotrophic situation at BATS. We found no need to change any of their model parameters. For our purpose, we have added a bromoform compartment $B$ (in nmol $\mathrm{CHBr}_{3} \mathrm{~m}^{-3}$ ) that evolves due to internal sources $(Q)$ and sinks $(S)$ as well as vertical diffusion:

$$
\frac{\partial B}{\partial t}=Q-S+\frac{\partial}{\partial z}\left(A_{v} \frac{\partial B}{\partial z}\right)
$$

where $A_{v}$ is the time- and depth-dependent turbulent vertical diffusivity coefficient.

The source terms are either coupled to primary production $\left(Q_{1}\right)$ or to the total phytoplankton losses $\left(Q_{2}\right)$

$$
\begin{aligned}
& Q_{1}=\beta \times \mu \times P \\
& Q_{2}=\beta^{*} \times\left(\gamma \times P^{2}+r \times P+g_{Z} \times Z\right)
\end{aligned}
$$

Here, $P$ and $Z$ are the phytoplankton and zooplankton concentrations, respectively (in mmol $\mathrm{N} \mathrm{m}^{-3}$ ), $\mu$ is the actual (in situ) growth rate of phytoplankton, $\gamma$ is the mortality rate of phytoplankton, $r$ and $g_{Z}$ are phytoplankton respiration and phytoplankton-dependent grazing rates of the NPZD model. We call the bromoform production to phytoplankton production ratio $\beta$, and a conceptually similar bromoform production to phytoplankton loss ratio $\beta^{*}$.

These proportionality factors were computed based on a suite of laboratory studies which report bromoform increase during the exponential growth phase of phytoplankton (Moore et al., 1996). First, we extracted the maximum specific growth rates $\omega$ of the three species under investigation from the exponential phase ${ }^{1}$; then the corresponding temporal changes in bromoform concentrations $\left(\triangle \mathrm{CHBr}_{3}\right)$ over time interval $\Delta t$ were used to determine the bromoform production to phytoplankton production ratio according to

$\beta=\frac{\Delta \mathrm{CHBr}_{3}}{\Delta t \times \omega P_{0}} \times e^{-\omega \Delta t}$

\footnotetext{
${ }^{1}$ Since temporal changes $(\Delta t)$ in cell counts are the result of the actual growth rate but not the maximum specific growth rate, we account for a respiration of $1 \% \mathrm{~d}^{-1}$.
}

The resulting values for $\beta$ are 4.2, 6.71, and $6.73 \times 10^{-7} \mathrm{nmol} \quad \mathrm{CHBr}_{3} \quad(\mathrm{mmolN})^{-1}$, using typical cellular carbon contents of the species (Wasmund, pers comm.: $176 \mathrm{pg} \mathrm{Cell}^{-1}$ for Nitzschia sp. and Nitzschia arctica, $2015 \mathrm{pgCcell}^{-1}$ for Porosira glacialis) and the Redfield ratio for conversion into nitrogen. The first value stems from an experiment (with Nitzschia arctica) which has been terminated prematurely (i.e., during the exponential growth phase). We therefore choose the average of the other two $\beta=6.72 \times 10^{-7} \mathrm{nmol} \mathrm{CHBr}_{3}(\mathrm{mmol} \mathrm{N})^{-1}$ for our numerical experiments. Note that this ratio might vary between different functional groups. However, since no further data are available, we assume that this value is appropriate even though obtained for cold water diatoms. The presence of bromoperoxidase enzymes (which are necessary for bromoform production) in diatoms, cyanobacteria, and Prymnesiophyceae (Moore et al., 1996; Jakopitsch, 2001; Hughes et al., 2006; Karlsson et al., 2008), however, might indicate that more species are involved in bromoform production. This is an area that needs further research.

An alternative interpretation of the laboratory experiments by Moore et al. (1996) is that bromoform production is correlated with the release of bromoperoxidase from the phytoplankton cell as a result of respiration and during the death of the cell. Hence, a similar approach leads to the formulation $Q_{2}$ and $\beta^{*}$ can be determined from the decay phase in Moore et al. (1996)'s experiments. These data are more difficult to extract, but it seems that $\beta^{*}$ is close to $\beta$, so for simplicity we assume them to be equal.

Bromoform is lost from the ocean through outgassing:

$\left.F\right|_{z=0}=k \times\left(B_{\text {equi }}-\left.B\right|_{z=0}\right)$

using the gas transfer velocity $k$ after Nightingale et al. (2000) and the atmospheric equivalent concentration $B_{\text {equi }}$ (based on the parameterisation by Moore et al., 1995).

Four different processes are assumed to play a role as internal sinks for bromoform: photolysis, halide substitution and hydrolysis, degradation (debromination) during remineralisation of detritus and nitrification.

Photolysis is considered in all experiments. We use a depth-decreasing time scale for degradation by ultraviolet radiation according to

$S_{0}=l_{u v} \times \frac{\mathrm{I}_{0}}{\mathrm{I}_{\text {ref }}} \times \exp \left(-a_{w} \times z\right) \times B$

where $\mathrm{I}_{0}$ denotes the instantaneous surface irradiance, $\mathrm{I}_{\mathrm{ref}}$ is the annual average irradiance for the uppermost meter in this region $\left(75 \mathrm{~W} \mathrm{~m}^{-2}\right), a_{w}$ the attenuation coefficient for UVlight $\left(0.33 \mathrm{~m}^{-1}\right)$ and $z$ the depth (positive downward). The decay time scale $\left(l_{u v}\right)^{-1}$ is 30 days as given by Carpenter and Liss (2000). Due to the short penetration depth of ultraviolet radiation, photolysis can only play a role in the surface mixed layer. In addition, we have implemented the following loss terms: 
Table 1. Overview of experiments and selected results: observed and simulated bromoform concentrations $\left(\mathrm{nmol} \mathrm{CHBr}_{3} \mathrm{~m}^{-3}\right)$ at the surface and in the subsurface maximum as well as air-sea flux $\left(\mathrm{pmol} \mathrm{CHBr}_{3} \mathrm{~m}^{-2} \mathrm{~h}^{-1}\right)$ for the month of November. Observed data are averages of offshore stations from the cruise M55 (Quack et al., 2004).

\begin{tabular}{cccccc}
\hline & $\begin{array}{c}\mathrm{CHBr}_{3} \\
\text { source }\end{array}$ & $\begin{array}{c}\mathrm{CHBr}_{3} \\
\text { sink }\end{array}$ & $\begin{array}{c}\text { surf. conc. } \\
\mathrm{nmol} \mathrm{m}{ }^{-3}\end{array}$ & $\begin{array}{c}\text { max. conc. } \\
\mathrm{nmol} \mathrm{m}^{-3}\end{array}$ & $\begin{array}{c}\text { air-sea flux } \\
\mathrm{pmol} \mathrm{m}^{-2} \mathrm{~h}^{-1}\end{array}$ \\
\hline M55 (observations) & & & 5.0 & 24.8 & 175 \\
EXP1 & $Q_{1}$ & $S_{1}$ & 6.5 & 21.5 & 163 \\
EXP2 & $Q_{1}$ & $S_{2}$ & 6.5 & 20.9 & 169 \\
EXP3 & $Q_{1}$ & $S_{3}$ & 6.7 & 23.6 & 188 \\
EXP4 & $Q_{2}$ & $S_{3}$ & 6.7 & 23.6 & 188 \\
\hline
\end{tabular}

- halide substitution and hydrolysis is assumed to be constant throughout the water column. A constant decay rate $l_{\text {con }}$ for $\mathrm{CHBr}_{3}$ is used, where the exponential time scale $\left(l_{\text {con }}\right)^{-1}=6.33$ years (a half life of 4.37 years) is at the lower end of the range of the estimated half life of bromoform (halide substitution, hydrolysis) from observations (5-74 years, Quack and Wallace, 2003):

$$
S_{1}=S_{0}+l_{\text {con }} \times B
$$

This approach is the most simple choice, as it requires the specification of only one parameter.

- bromoform degradation (and reductive debromination) is related to the remineralisation of detritus $(D)$ (following Fetzner, 1998; Quack et al., 2007b), using an exponential decay time scale of $\left(l_{\text {rem }}\right)^{-1}=7.92$ years (half life: 5.49 years), and taking into account the temperature dependence for remineralisation from the NPZD model:

$S_{2}=S_{0}+l_{\text {rem }} \times \frac{D}{D_{\text {ref }}} \times 1.066^{T} \times B$

The reference concentration for detritus is $D_{\text {ref }}=0.13 \mathrm{mmol} \mathrm{N} \mathrm{m}^{-3}$.

- as a (crude) parameterisation for the degradation of $\mathrm{CHBr}_{3}$ by nitrifiers the decay rate has been inversely coupled to the light field I, assuming that nitrification (ammonium oxidation) is inhibited by high light levels (Olson, 1981). To our knowledge, no empirical information exists about the light dependence of nitrification limitation. We therefore adopt the functional dependence of the phytoplankton light limitation to describe this process based on $24 \mathrm{~h}$ averages of irradiance:

$$
S_{3}=S_{0}+l_{\text {nit }}\left(1-\frac{\frac{a}{24 \mathrm{~h}} \int_{t-24 \mathrm{~h}}^{t} \mathrm{I}(z) d t}{\sqrt{\lambda^{2}+\left(\frac{a}{24 \mathrm{~h}} \int_{t-24 \mathrm{~h}}^{t} \mathrm{I}(z) d t\right)^{2}}}\right) \times B
$$

The exponential decay time scale is assumed to be $\left(l_{\text {nit }}\right)^{-1}=4$ years (half life: 2.74 years); the additional parameters are $a=3.0 \times 10^{-5} \mathrm{~m}^{2} \mathrm{~W}^{-1} \mathrm{~s}^{-1}$ and $\lambda=3.1 \times 10^{-6} \mathrm{~s}^{-1}$. We assume that ammonium oxidation is not limited by temperature or oxygen.

Note that the decay rates have been chosen in order to obtain the best correspondence between modelled and observed profiles.

In this paper, we shall present results from four experiments, which use different combinations of source and sink terms (see Table 1).

\subsection{Forcing and initialisation}

The model is forced by climatological monthly means of 2$\mathrm{m}$ atmospheric temperature, air pressure and dew point temperature, $10-\mathrm{m}$ zonal and meridional wind velocities, cloud cover as well as precipitation based on ERA40 reanalysis (Uppala et al., 2005). The physical variables temperature and salinity are initialised with climatological profiles from the World Ocean Atlas (WOA01) (Conkright et al., 2002). Lateral effects in the one-dimensional model are taken into account by restoring salinity and temperature (except for the upper $20 \mathrm{~m}$ ) towards climatological monthly means of WOCE with a five day-timescale. All biogeochemical variables are initialised homogeneously except nitrogen for which the vertical profile of dissolved inorganic nitrogen derived from measurements at Cape Verde (Bange, 2007) has been taken. At the bottom, the DIN concentration is restored to the observed value of $35.7 \mathrm{mmol} \mathrm{m}^{-3}$ with a relaxation time scale of one hour. The atmospheric concentration of $\mathrm{CHBr}_{3}$ is set constant, using a value of $0.14 \mathrm{nmol} \mathrm{m}^{-3}$ (3.4 ppt) which is a mean (and typical) value for atmospheric bromoform concentrations in that particular region (Quack et al., 2004). Although initialization and forcing fields are from Cape Verde at $17.4^{\circ} \mathrm{N}, 24.5^{\circ} \mathrm{W}$, we believe that our results are representative for the entire eastern tropical Atlantic Ocean. Additional model runs at locations further south show only small changes in the depth of the mixed 


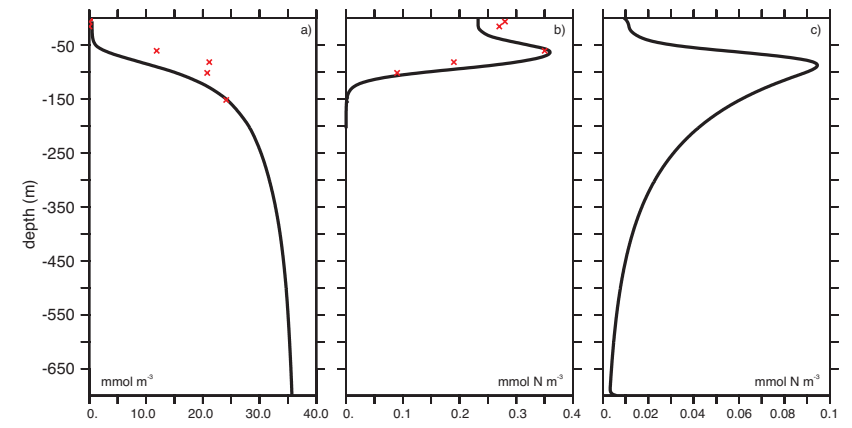

Fig. 1. Simulated vertical profiles of (a) nutrients, (b) phytoplankton and c) detritus from November. Measurements (red crosses) have been performed in November 2002 during the cruise M55. Phytoplankton concentrations have been derived from chlorophyll, using a vertically dependent C:Chl-ratio $\left(175 \mathrm{~g} \mathrm{~g}^{-1}\right.$ at surface, $25 \mathrm{~g} \mathrm{~g}^{-1}$ in $200 \mathrm{~m}$ depth, (see e.g., Hense and Beckmann, 2008) and the Redfield ratio for conversion from carbon to nitrogen.

layer and location of the subsurface phytoplankton biomass and bromoform maxima. The profiles of the individual experiments are similar and conclusions are unaffected by this change in geographical location.

\section{Results and discussion}

The model has been run for 50 years after which a perpetual seasonal cycle developed; we have analysed the last year. The relatively long spin-up time is required for the slowly evolving bromoform distribution. The physical fields reach a periodically steady state after about 6 years, the biological variables after about 10 years.

\subsection{Hydrographic and biogeochemical characteristics}

Our simulation of the physical conditions at Cape Verde reproduces the temperature and salinity fields reasonably well (see appendix, Fig. 7). The vertical profiles of salinity show a subsurface salinity maximum at about $100 \mathrm{~m}$ depth which is a feature of the tropical eastern North Atlantic Ocean resulting from the intrusion of more saline South Atlantic Central Water (SACW) from the South Atlantic. As expected for this region, the thermocline starts between 50 and $100 \mathrm{~m}$.

The vertical profile of nutrient shows a depletion in the upper $50 \mathrm{~m}$ (Fig. 1) due to the uptake by phytoplankton and subsequent sinking of dead particulate organic matter. The maximum concentrations of phytoplankton biomass are found subsurface in the upper nutricline where light and nutrient supply are optimal. Due to sinking, the detritus maximum is located below the phytoplankton maximum.

In general, the modelled concentrations of both phytoplankton biomass and nutrients agree well with observations from that region (Fig. 1). The remaining discrepancies (e.g., slightly lower surface phytoplankton values) are due to the

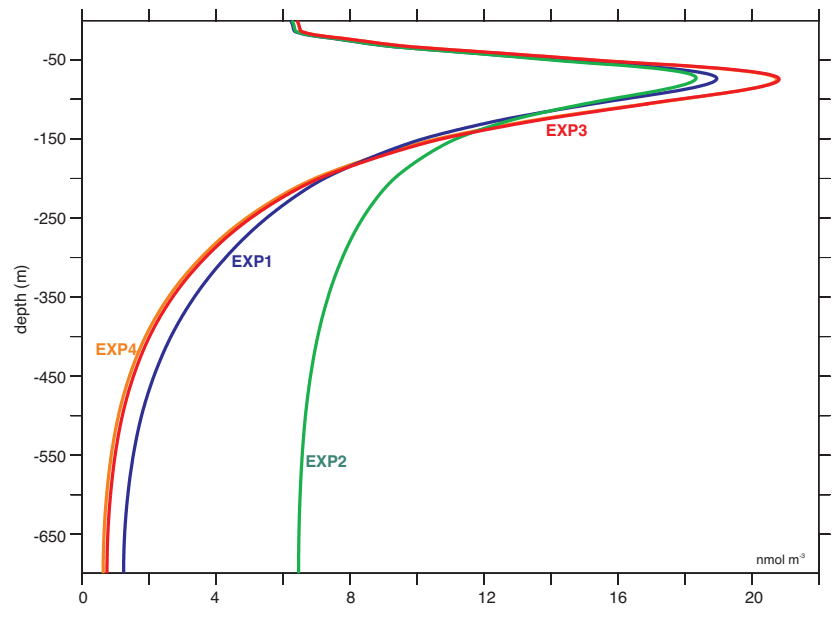

Fig. 2. Simulated annual mean vertical profiles of bromoform from the different experiments.

differences in the temporal (and spatial) resolution; while the field data are point measurements in a spatially heterogeneous environment, the model solutions represent averages in space and time (over a month).

\subsection{Vertical distribution of bromoform}

As expected for a phytoplankton related source of $\mathrm{CHBr}_{3}$ in the oligotrophic ocean, the simulated annual mean vertical distribution of bromoform shows a pronounced subsurface maximum in all experiments (Fig. 2, Table 1). The maximum is located in $66 \mathrm{~m}$ depth, a few meters below the phytoplankton biomass maximum within a layer characterized by the strongest temperature and nutrient gradients.

We note that differences between the experiments are smallest at the surface and largest below $200 \mathrm{~m}$ depth. The surface concentrations are controlled by the air-sea flux, photolysis and entrainment, which are similar in all experiments (Fig. 3). The subsurface concentration of $\mathrm{CHBr}_{3}$ in the water column, however, depends strongly on the assumed internal decay process (Fig. 3d).

The most striking difference between our experiments are the comparatively high concentrations of $\mathrm{CHBr}_{3}$ below $200 \mathrm{~m}$ depth in EXP2 (Fig. 2, green line). This means that degradation coupled to remineralisation leads to high concentrations at depth, because most of the temperaturedependent remineralisation takes place in the warmer water column above $200 \mathrm{~m}$ depth. Hence, bromoform accumulates in the deep ocean. This feature is related to the biogeochemical model and its values for detrital sinking and temperature dependent remineralisation rates. The few available observational data of $\mathrm{CHBr}_{3}$ concentrations below $200 \mathrm{~m}$ show that the concentration at $630 \mathrm{~m}$ is close to $1.0 \mathrm{nmol} \mathrm{CHBr}_{3}$ $\mathrm{m}^{-3}$ (Quack, unpublished data, 2004). While similar concentrations can be found for EXP1, EXP3 and EXP4 (0.8$1.3 \mathrm{nmol} \mathrm{CHBr}_{3} \mathrm{~m}^{-3}$ ), they are significantly higher in EXP2 

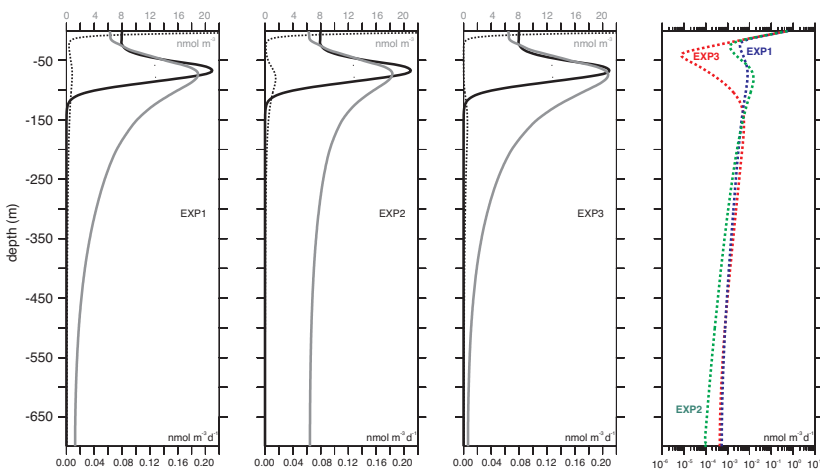

Fig. 3. Simulated annual mean vertical profiles of production (solid black line), loss (dotted black line) and bromoform (grey line, $\left[\mathrm{nmol} \mathrm{m}{ }^{-3}\right]$ ) for the EXP1-EXP3 (EXP4 is similar to EXP3 and thus omitted). For a better visualization of the losses an additional plot with logarithmic scale (same color coding as in Fig. 2) is included (right).

$\left(6.5 \mathrm{nmol} \mathrm{CHBr}_{3} \mathrm{~m}^{-3}\right)$ indicating that the degradation is underestimated. One obvious way to decrease the deep $\mathrm{CHBr}_{3}$ concentrations in EXP2 is to increase $l_{\text {rem }}$, but then the subsurface maximum is too small.

The other three experiments show similar vertical profiles. In particular, we note that the type of bromoform source $\left(Q_{1}\right.$ vs. $\left.Q_{2}\right)$ has hardly an effect on the annual mean profiles. However, we do find a time delay of about two days in the seasonal succession of bromoform production for EXP4 compared to EXP3, simply because primary prodcution precedes mortality and grazing. At the surface the largest differences occur in winter, at the depth of the maximum in summer due to the anticorrelation between surface and subsurface primary production. Overall, the differences are small $(<1 \%)$. This is both encouraging and disappointing: on the one hand we do not need to know more about the details of the production process to obtain a realistic result; on the other hand we cannot use our experiments to distinguish the different hypotheses. The most pronounced maximum and the largest gradient of bromoform are produced in EXP3 and EXP4 (Fig. 2, red lines). A slightly reduced subsurface maximum of $\mathrm{CHBr}_{3}$ and higher concentrations at $700 \mathrm{~m}$ depth are found in EXP1 (Fig. 2, blue curve).

A more quantitative evaluation of the model results can be performed for the month of November. Observations of bromoform in the eastern North Atlantic Ocean down to $200 \mathrm{~m}$ are available for a number of stations from a cruise in the beginning of November 2002 (Quack et al., 2004). Spatial (and to a lower degree temporal) variability yields profiles that differ in depth, thickness and amplitude of bromoform maximum layers. Our one-dimensional water column model, forced by climatological fields, does not represent an individual observed profile. Therefore, we have constructed a "typical" (averaged) $\mathrm{CHBr}_{3}$ distribution, applying the method of Hense and Beckmann (2008): Instead of av-

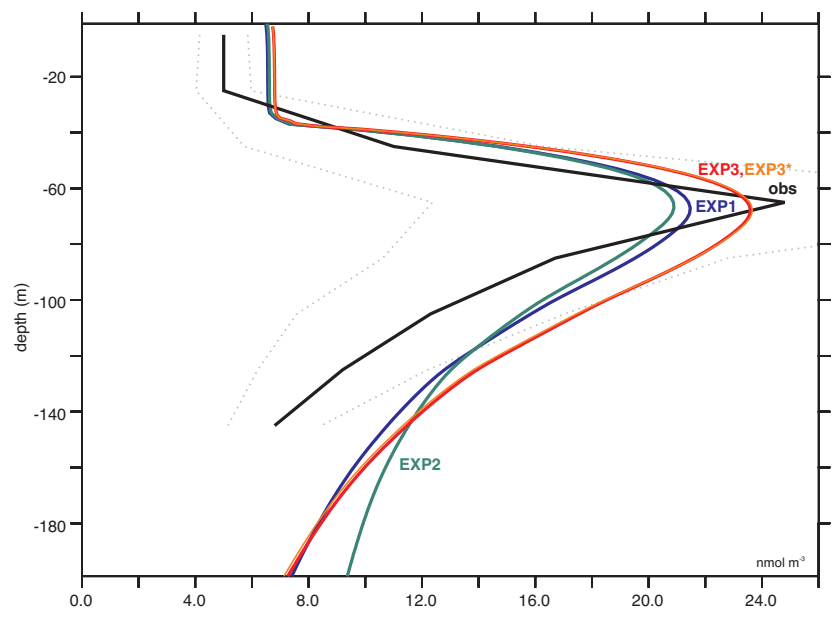

Fig. 4. Vertical profiles of observed (obs: black line) and simulated (EXP1: blue line, EXP2: green line, EXP3: red line) $\mathrm{CHBr}_{3}$ concentrations from November. $\mathrm{CHBr}_{3}$ profiles of stations which were closest to the Cape Verde station (area: $10.5-11.97^{\circ} \mathrm{N}, 16.83-$ $25^{\circ} \mathrm{W}$ ) from the cruise M55 in November 2002 (Quack et al., 2004) have been adjusted to the depth of the maximum of bromoform according to the method introduced by Hense and Beckmann (2008). The grey dotted lines indicate the standard deviation; the maximum is at $37 \mathrm{nmol} \mathrm{m}^{-3}$.

eraging along depth horizons, all the maxima are aligned to obtain a "mean" profile (Fig. 4). The advantage of this approach is that two important characteristics of the distributions (amplitude and thickness) are reliably preserved while the drawback is that absolute depth information is lost (see Hense and Beckmann, 2008). Figure 4 should therefore be used only to compare amplitude and thickness between this composite of observations and the simulated profiles.

The model-data comparison for EXP1-EXP3 shows that the simulated vertical distribution patterns of $\mathrm{CHBr}_{3}$ capture the most important features of the observations: the magnitude of the subsurface maximum, a strong decrease upward to the surface and a somewhat slower decrease downward (Fig. 4). Given the uncertainties of model parameters and forcing, the robustness of the results support the validity of our assumptions.

The systematic overestimation of the surface concentration in all experiments may be due to the use of a constant atmospheric bromoform concentration and the climatological wind fields which both affect the air-sea flux. Additional sensitivity experiments indicate that slightly changed atmospheric data can easily account for concentration changes of $2 \mathrm{nmol} \mathrm{CHBr}_{3} \mathrm{~m}^{-3}$ in the surface mixed layer.

Differences between simulations and observations occur also with respect to the thickness of the bromoform maximum layer. The observed "typical" profile of bromoform has a thickness of about $60 \mathrm{~m}$ (based on a "full width at half maximum" criterion). The simulated profiles show thicker maximum layers (EXP1: $105 \mathrm{~m}, \mathrm{EXP} 2: 126 \mathrm{~m}, \mathrm{EXP} 3$ and 


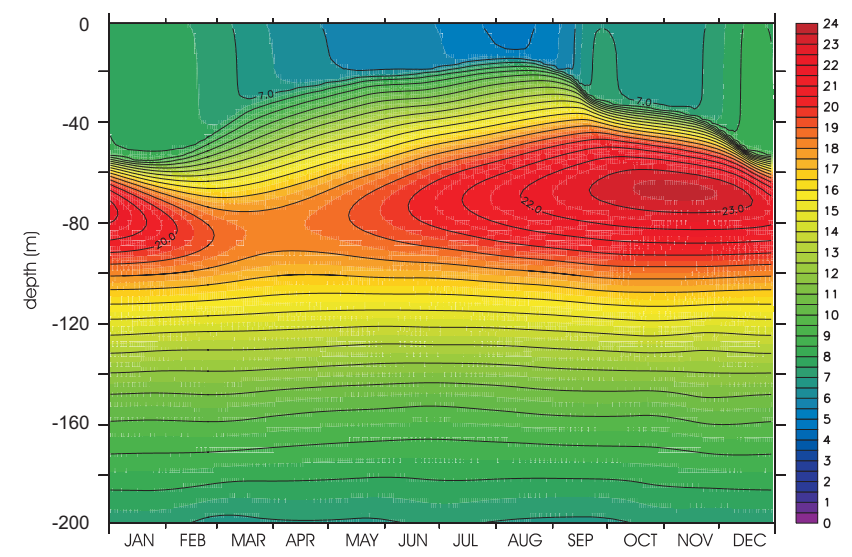

Fig. 5. Seasonal cycle of simulated bromoform concentrations in EXP3 in the upper $200 \mathrm{~m}$. The contour interval is $1 \mathrm{nmol} \mathrm{CHBr}_{3}$ $\mathrm{m}^{-3}$.

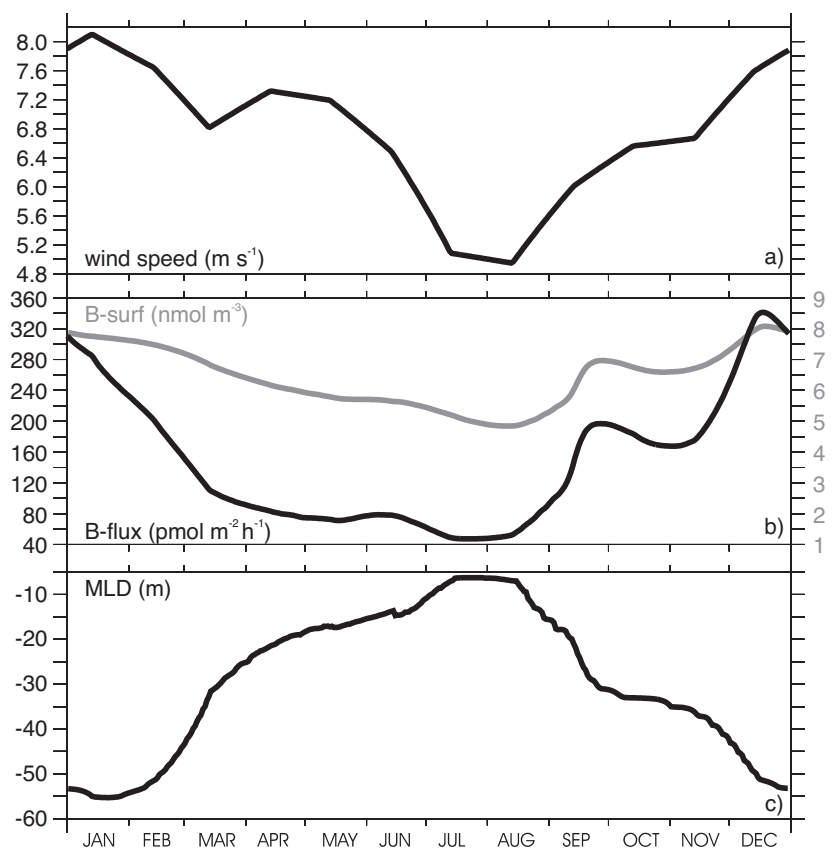

Fig. 6. Seasonal cycle of (a) wind speed, (b) air-sea flux (solid black line, left axis) and surface concentrations (grey line, right axis) of bromoform and (c) mixed layer depth in EXP3.

EXP4: $100 \mathrm{~m}$ ), most likely due to an overestimation of the thickness of the subsurface biomass maximum by the ecosystem model. Simultaneous measurements of bromoform and phytoplankton biomass at high vertical resolution would be required to make conclusive statements in this respect.

As mentioned before, the largest maxima and the steepest downward gradients of bromoform are obtained for $S_{3}$, the "nitrification case" (Fig. 4, red curve). This is a consequence of the vertical separation of the production layer from the destruction layer below. It seems that the observed profiles
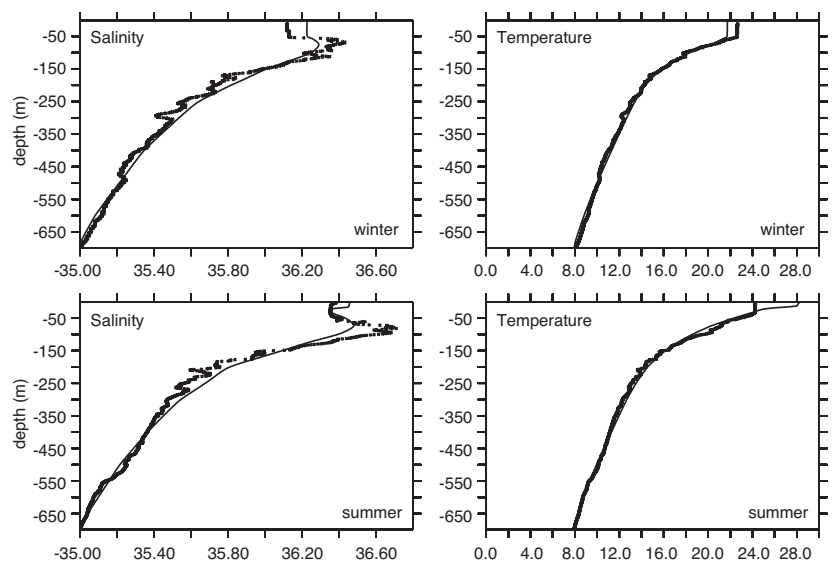

Fig. 7. Observed (crosses) and simulated (solid line) salinity (left) and temperature $\left({ }^{\circ} \mathrm{C}\right.$, right) in winter (February, upper panels) and summer (August, lower panels) at Cape Verde.

can be best explained by adjacent, non-overlapping internal source and sink layers.

The quantitative evaluation of our model results shows that the concentration in the subsurface maximum is best represented by EXP3 or EXP4 (Table 1). Overall, however, the differences in the concentrations of bromoform in the upper $200 \mathrm{~m}$ between the experiments, particularly EXP1 and EXP3 are rather small. This is also true with respect to airsea fluxes: The simulated flux from the ocean into the atmosphere ranges only between $163-188 \mathrm{pmol} \mathrm{CHBr}_{3} \mathrm{~m}^{-2} \mathrm{~h}^{-1}$ for November for the individual experiments. They are close to the observed $175 \mathrm{pmol} \mathrm{CHBr}_{3} \mathrm{~m}^{-2} \mathrm{~h}^{-1}$ in this region (Table 1).

A sensitivity experiment with photolysis as the only internal loss process resulted in an imbalance between sources and sinks below the subsurface maximum and led to unrealistically high and continuously increasing subsurface bromoform concentrations (no steady state is reached within 100 years of model integration). Conversely, omitting photolytic destruction leads to an increase in the surface concentrations and a higher air-sea flux (8-36\%).

In summary, EXP3 shows the best agreement with observations and thus, for further analyses, we focus on the results of this case.

\subsection{Simulated seasonal cycle of bromoform and air-sea fluxes}

Having established that the model does represent the main features of the observed bromoform distribution reasonably well, we can now look at unobserved aspects of the problem, e.g., the seasonal cycle. The highest subsurface maximum of bromoform ( $>24 \mathrm{nmol} \mathrm{CHBr}_{3} \mathrm{~m}^{-3}$ at around $66 \mathrm{~m}$ ) occurs in late autumn while the lowest concentrations can be found in spring ( $<18 \mathrm{nmol} \mathrm{CHBr}_{3} \mathrm{~m}^{-3}$ in about $80 \mathrm{~m}$, Fig. 5). 
We note a time delay of about one month between the occurrence of the subsurface maximum and the occurrence of the surface mixed layer maximum, related to the gradual deepening of the surface mixed layer and the entrainment of the bromoform signal (Figs. 5, 6). The lowest subsurface concentrations are found in April. During spring and summer, the surface layer is essentially decoupled from the subsurface bromoform production layer and the surface concentrations decrease until early August.

The seasonal cycle of bromoform surface concentration and air-sea flux shows winter maximum and summer minimum (Fig. 6). Concentrations vary by a factor less than two, fluxes by a factor of almost ten. It is important to note that the seasonal flux variations are only partly caused by the variations in production; the variability in mixed layer depth, which in turn is driven by changes in heat and freshwater fluxes as well as the wind speed, is the main factor. While the absolute maximum of the air-sea flux occurs in winter, secondary maxima are found in early summer and autumn (Fig. 6). From April to June relatively high wind speeds (Fig. 6c) promote the outgassing from the surface ocean. In September and October, the combined effect of the increasing wind speed and the deepening of the mixed layer (Fig. 6a, c) inducing the entrainment of bromoform into the surface layer leads to a rapid increase in the air-sea flux (Fig. 6b). We notice that the temporal variation of bromoform in the water column is similar in all our experiments irrespective of differences in the absolute subsurface concentrations.

\section{Summary and conclusions}

We have simulated the climatological seasonal cycle of the vertical distribution of bromoform in the upper $700 \mathrm{~m}$ of the tropical eastern Atlantic Ocean. Using the results from laboratory experiments (Moore et al., 1996) bromoform production has been coupled to the growth and losses of phytoplankton, respectively. The differences between these two approaches are marginal and leave open the question of which physiological processes are ultimately responsible for the production of $\mathrm{CHBr}_{3}$. The generally good agreement of the model results with observations, however, suggests that the subsurface maximum can be entirely explained by in-situ production in which phytoplankton plays the most important role. This result is of more general relevance because observations indicate that the subsurface bromoform maximum is an ubiquitous feature of the eastern tropical Atlantic Ocean (Quack et al., 2004, 2007b).

Our numerical experiments with different degradation mechanisms of $\mathrm{CHBr}_{3}$ show that besides the near surface processes photolysis and air-sea flux, additional water column losses are necessary to explain the downward decrease in concentrations below the subsurface maximum. Among the three cases we compared, the experiment with a degradation proportional to nitrification (parameterised by an inverse proportionality to the light field) is in best agreement with observations, i.e., it has the most pronounced maximum and the lowest deep concentration of bromoform. This is achieved by the vertical separation of the bromoform production layer from the bromoform destruction layer below. In the assessment of our model results we have to keep in mind that although we have investigated the various bromoform degradation mechanisms individually, they are likely to be active simultaneously (at unknown relative strengths). In any case, nitrification-related degradation of bromoform seems essential in generating the observed vertical bromoform distribution. This is not an unreasonable result, given that observations point at a co-metabolism of $\mathrm{CHBr}_{3}$ in the presence of some nitrifiers (Wahman et al., 2005). In addition, recently obtained field data show a maximum of dibromomethane (a degradation product of $\mathrm{CHBr}_{3}$ from reductive debromination processes) below the maximum of $\mathrm{CHBr}_{3}$ (Quack, unpublished data, 2004, Butler et al., 2007). Further studies on subsurface bromoform degradation are clearly needed.

The model results further suggest that the seasonality of oceanic bromoform outgassing is larger than often assumed. While surface concentrations range from 5 to $8 \mathrm{nmol} \mathrm{CHBr}_{3}$ $\mathrm{m}^{-3}$ (summer versus winter), the air-sea flux varies by almost an order of magnitude. Strongly controlled by the seasonal changes in wind speed and mixed layer depth, outgassing is $40 \mathrm{pmol} \mathrm{CHBr}_{3} \mathrm{~m}^{-2} \mathrm{~h}^{-1}$ in summer and $360 \mathrm{pmol}$ $\mathrm{CHBr}_{3} \mathrm{~m}^{-2} \mathrm{~h}^{-1}$ in winter. Note that the use of seasonally varying atmospheric concentrations of $\mathrm{CHBr}_{3}$ will lead to (probably minor) quantitative changes in these values.

The vertically integrated annual production rate of bromoform in the model is $4.6 \mu \mathrm{mol} \mathrm{CHBr}_{3} \mathrm{~m}^{-2} \mathrm{a}^{-1}$ (525 pmol $\mathrm{CHBr}_{3} \mathrm{~m}^{-2} \mathrm{~h}^{-1}$ ) with a corresponding annual mean air-sea flux of 1.1-1.3 $\mu \mathrm{mol} \mathrm{CHBr}_{3} \mathrm{~m}^{-2} \mathrm{a}^{-1}$ (125-148 $\mathrm{pmol} \mathrm{CHBr}_{3}$ $\mathrm{m}^{-2} \mathrm{~h}^{-1}$ ) for the different experiments; i.e., about $25 \%$ of the production is transferred to the atmosphere. There, as a carrier of bromine, $\mathrm{CHBr}_{3}$ of phytoplanktonic origin will contribute to the destruction of ozone and thus should be included in budget calculations.

\section{Appendix A}

\section{Observed and modelled salinity and temperature profiles}

Simulated temperature and salinity profiles have been compared with observed summer and winter values at the TENATSO station. The differences are rather small. This is the result of the restoring towards climatological monthly means, which prevents model drift (Fig. 7).

Acknowledgements. Valuable comments by and fruitful discussions with Aike Beckmann have substantially improved the manuscript. Ilka Peeken provided phytoplankton pigment measurements. We thank the two anonymous reviewers for their constructive criticism. 
This study has been financed by the German BMBF project SOPRAN 03F0462.

Edited by: S. W. A. Naqvi

\section{References}

Abrahamsson, K., Lorén, A., Wulff, A., and Wangberg, S.-A.: Airsea exchange of halocarbons: the inuence of diurnal and regional variations and distribution of pigments, Deep-Sea Res. Pt. II, 29, 2789-2805, 2004.

Bange, H. W.: Physical oceanography at CTD station PO320, Cruise report R.V. Poseidon, cruise PO320/1, IFM-GEOMAR, Leibniz-Institut für Meereswissenschaften an der ChristianAlbrechts-Universität, Kiel, Germany, 2007.

Beckmann, A. and Hense, I.: Beneath the surface: Characteristics of oceanic ecosystems under weak mixing conditions - a theoretical investigation, Prog. Oceanogr., 75, 771-796, 2007.

Burchard, H., Bolding, K., Kühn, W., Meister, A., Neumann, T., and Umlauf, L.: Description of a flexible and extendable physical biogeochemical model system for the water column, J. Mar. Syst., 61, 180-211, 2006.

Butler, J. H., King, D. B., Lobert, J. M., Montzka, S. A., YvonLewis, S. A., Hall, B. D., Warwick, N. J., Mondeel, D. J., Aydin, M., and Elkins, J. W.: Oceanic distributions and emissions of short-lived halocarbons, Global Biogeochem. Cy., 21, GB1023, doi:10.1029/2006GB002732, 2007.

Carpenter, L. and Liss, P. S.: On temperate sources of bromoform and other reactive organic bromine gases, J. Geophys. Res., C, 105, 20539-20547, 2000.

Conkright, M. E., Locarnini, R. A., Garcia, H. E., O’Brien, T. D., Boyer, T. P., Stephens, C., and Antonov, J. I.: World Ocean Atlas 2001: Objective Analyses, Data Statistics, and Figures, CDROM Documentation, Tech. rep., National Oceanographic Data Center, Silver Spring, MD, USA, 2002.

Fairall, C. W., Bradley, E. F., Rogers, D. P., Edson, J. B., and Young, G. S.: Bulk parameterization of air-sea fluxes for tropical oceanglobal atmosphere coupled-ocean atmosphere response experiment, J. Geophys. Res., C, 101, 3747-3764, 1996.

Fetzner, S.: Bacterial dehalogenation, Appl. Microbiol. Biotechnol., 50, 633-657, 1998.

Geen, C. E.: Selected marine sources and sinks of bromoform and other low molecular weight organobromines, Ph.D. thesis, Dalhousie, Univ. Halifax, Nova Scotia, Canada, 1992.

Hense, I. and Beckmann, A.: Revisiting subsurface chlorophyll and phytoplankton distributions, Deep-Sea Res. Pt. I, 55, 1193-1199, doi:10.1016/j.dsr.2008.04.009, 2008.

Hughes, C., Malin, G., Nightingale, P. D., and Liss, P.: The effect of light stress on the release of volatile iodocarbons by three species of marine microalgae, Limnol. Oceanogr., 51, 2849-2854, 2006.

Jakopitsch, C.: Catalase-peroxidase from Synechocystis is capable of chlorination and bromination reactions, Biochemical and biophysical research communications, 287-682, 2001.

Karlsson, A., Auer, N., Schulz-Bull, D., and Abrahamsson, K.: Cyanobacterial blooms in the Baltic- A source of halocarbons, Mar. Chem., 110, 129-139, 2008.

Manley, S. L.: Phytogenesis of halomethanes: A product of selection or a metabolic accident?, Biogeochemistry, 60, 163-180, 2002.
Martínez-Marrero, A., Rodríguez-Santana, A., Hernández-Guerra, A., Fraile-Nuez, E., López-Laatzen, F., Vélez-Belchí, P., and Parrilla, G.: Distribution of water masses and diapycnal mixing in the Cape Verde Frontal Zone, Geophys. Res. Lett., 35, L07609, doi:10.1029/2008GL033229, 2008.

Moore, R. M. and Tokarczyk, R.: Volatile biogenic halocarbons in the northwest Atlantic, Global Biogeochem. Cy., 7, 195-210, 1993.

Moore, R. M., Geen, C. E., and Tait, V. K.: Determination of Henrys law constants for a suite of naturally occuring halogenated methanes in seawater, Chemosphere, 30, 1183-1191, 1995.

Moore, R. M., Webb, M., Tokarczyk, R., and Wever, R.: Bromoperoxidase and iodoperoxidase enzymes and production of halogenated methanes in marine diatom cultures, J. Geophys. Res., C, 101, 20899-20908, 1996.

Nightingale, P. D., Malin, G., Law, C. S., Watson, A. J., Liss, P., Liddicoat, M. I., Boutin, J., and Upstill-Goddard, R. C.: In situ evaluation of air-sea gas exchange parameterizations using novel conservative and volatile tracers, Global Biogeochem. Cy., 14, 373-387, 2000.

Olson, R.: Differential photoinhibition of marine nitrifying bacteria: A possible mechanism for the formation of the primary nitrite maximum, J. Mar. Res., 39, 227-238, 1981.

Oschlies, A. and Schartau, M.: Basin-scale performance of a locally optimized marine ecosystem model, J. Mar. Res., 63, 335-358, 2005.

Quack, B. and Wallace, D. W. R.: Air-sea flux of bromoform: Controls, rates, and implications, Global Biogeochem. Cy., 17, 1023, doi:10.1029/2002GB001890, 2003.

Quack, B., Atlas, E., Petrick, G., Stroud, V., Schauffler, S., and Wallace, D. W. R.: Oceanic bromoform sources for the tropical atmosphere, Geophys. Res. Lett., 31, L23S05, doi:10.1029/2004GL020597, 2004.

Quack, B., Petrick, G., and Wallace, D. W. R.: Bromoform and dibromomethane above the Mauritanian upwelling: Atmospheric distributions and oceanic emissions, J. Geophys. Res., D, 112, doi:10.1029/2006JD007614, 2007a.

Quack, B., Peeken, I., Petrick, G., and Nachtigall, K.: Oceanic distribution and sources of bromoform and dibromomethane in the Mauritanian upwelling, J. Geophys. Res., C, 112, C10006, doi:10.1029/2006JC003803, 2007b.

Read, K. A., Mahajan, A. S., Carpenter, L. J., Evans, M. J., Faria, B. V. E., Heard, D. E., Hopkins, J. R., Lee, J. D., Moller, S. J., Lewis, A. C., Mendes, L., McQuaid, J. B., Oetjen, H., SaizLopez, A., Pilling, M. J., and Plane, J. M. C.: Extensive halogenmediated ozone destruction over the tropical Atlantic Ocean, Nature, 453, 1232-1235, 2008.

Schall, C., Heumann, K. G., Mora, S. D., and Lee, P. A.: Biogenic brominated and iodinated organic compounds in ponds on the McMurdo Ice Shelf, Antarctica, Antarct. Sci., 8, 45-48, 1996.

Schartau, M. and Oschlies, A.: Simultaneous data-based optimization of a 1D-ecosystem model at three locations in the North Atlantic Ocean: Part I: Method and parameter estimates, J. Mar. Res., 61, 765-793, 2003.

Sturges, W. T., Oram, D. E., Carpenter, L. J., Penkett, S. A., and Engel, A.: Bromoform as a source of stratospheric bromine, Geophys. Res. Lett., 27, 2081-2084, 2000.

Umlauf, L., Bolding, K., and Burchard, H.: GOTM Scientific Documentation. Version 3.2, in: Marine Science Reports, Baltic Sea 
Research Institute, Warnemünde, Germany, 63, p. 231, 2005.

Uppala, S., Kallberg, P., Simmons, A., Andrae, U., da Costa Bechtold, V., Fiorino, M., Gibson, J., Haseler, J., Hernandez, A., Kelly, G., Li, X., Onogi, K., Saarinen, S., Sokka, N., Allan, R., Andersson, E., Arpe, K., Balmaseda, M., Beljaars, A., van de Berg, L., Bidlot, J., Bormann, N., Caires, S., Chevallier, F., Dethof, A., Dragosavac, M., Fisher, M., Fuentes, M., Hagemann, S., Holm, E., Hoskins, B., Isaksen, L., Janssen, P., Jenne, R., McNally, A., Mahfouf, J.-F., Morcrette, J.-J., Rayner, N., Saunders, R., Simon, P., Sterl, A., Trenberth, K., Untch, A., Vasiljevic, D., Viterbo, P., and Woollen, J.: The ERA-40 re-analysis, Q. J. Roy. Meteor. Soc., 131, 2961-3012, 2005.

Vogel, T. M., Criddle, C. S., and McCarthy, P. L.: Transformation of halogenated aliphatic compounds, Env. Sci. Technol., 21, 722736, 1987.
Wahman, D. G., Katz, L. E., and Speitel, J. G. E.: Cometabolism of Trihalomethanes by Nitrosomonas europaea, Appl. Environ. Microb., 71, 7980-7986, 2005.

Wallace, D. W. R. and Bange, H. W.: Introduction to special section: Results of the Meteor 55: Tropical SOLAS Expedition, Geophys. Res. Lett., 31, L23S01, doi:10.1029/2004GL021014, 2004.

Weber, L., Völker, C., Oschlies, A., and Burchard, H.: Iron profiles and speciation of the upper water column at the Bermuda Atlantic Time-series Study site: a model based sensitivity study, Biogeosciences, 4, 689-706, 2007, http://www.biogeosciences.net/4/689/2007/. 